of Australia. Further, we understand that a representative of this Association was deputed to discuss this with the trustees of the British Museum this summer. When can we expect to hear the result of this discussion?

\section{Research at Armstrong College}

From Armstrong College, Newcastle-upon-Tyne, we have received a report for 1935-36, somewhat belated, by the Standing Committee for Research. The importance of some of the work accomplished with the help of the Committee's small subventions (twenty-six grants amounting in the aggregate to $£ 846$ ) is well brought out in an eighteen-page summary prefixed to the individual reports of the recipients and list of publications. An obvious advantage of a fund such as that administered by the Committee, unappropriated in advance to specified fields, is that its administration compels representatives of different departments to take an interest in research in each other's fields, and this promotes inter-departmental collaboration in research, instances of which are cited in the report. Of the role of philosophy in the University, the Committee takes a liberal view, for it refers to works emanating from the College's Department of Philosophy as "original contributions towards the formation of that background of knowledge which forms, or should form, the background of university education".

\section{American Documentation Institute}

The American Documentation Institute was incorporated at a meeting in Washington on March 13 as a corporation "not for profit" but for educational, literary and scientific purposes. The first objective of the new organization is to develop and apply the new technique of microphotography to library, scientific and other material. This national organization was foreseen as an outline of the documentation activities of Science Service when they commenced in July 1935. Bibliofilm Service has been conducted by Science Service in co-operation with the Library of the U.S. Department of Agriculture as a service to research workers, and in auxiliary publication through microfilm, leading academic and scientific journals have co-operated.

\section{Cytological Technique}

A SHORT but useful pamphlet giving an "Outline of Cytological Technique for Plant Breeders" is issued by the Imperial Bureau of Plant Genetics (1s. 6d.). Genetics and cytology have become so intimately interwoven in their results that every plant breeder needs to have some knowledge not only of chromosome investigations but also of the methods of cytology. The various techniques involved are sufficiently exacting if satisfactory results are to be obtained. This pamphlet gives an account of the paraffin method, the smear method and a short statement containing the essentials of technique in the use of the microscope, the methods being based mainly on the schedules in use at the John Innes Horticultural Institution, Merton.

\section{Microscopy: the Quekett Microscopical Club}

Watson's Microscope Record of May (No. 41), among other matter, contains an account by $\mathrm{Mr}$. J. F. Stirling of the microscope used by John Dalton, now in the possession of the Manchester Literary and Philosophical Society, and an article by the editor on the appropriate eyepiece to use with certain objectives. Two new species of Bdelloid Rotatoria are described by Mr. W. E. Garner in the Journal of the Quekett Microscopical Club of April (Ser. 3, 1, No. 7, p. 280). Mr. W. E. Watson Baker is the new president of the Quekett Club, which is holding its annual conversazione on October 12 in the rooms of the Royal Society at Burlington House.

\section{Conference on Protection against Natural Disasters}

THE first "Conférence internationale pour la protection contre les calamités naturelles" is to be held at the Paris Exhibition on September 13-17. The following titles of sections of the Conference indicate its scope: vulcanology and seismology, meteorology, zoology and epidemiology, economic and social crises (fires, famines), assurances. The organizers of the Conference are the Commission Française d'études des calamités, one of a dozen such national com. missions which owe their existence to the initiative of the editorial board of the scientific periodical, Matériaux pour l'étude des calamités, established in 1924 by M. Raoul Montandon. In that year the Italian commission was formed. Its president is Giovanni Ciraolo, who is also president of the Union internationale de secours founded by the League of Nations in 1927, when the French commission was formed. Later, similar bodies were established in Austria, Belgium, Bulgaria, Chile, Czechoslovakia. Greece, Hungary, Italy and Switzerland. Others are in course of formation in Russia and Yugoslavia. The opening session will be presided over by the Under-Secretary of State for Scientific Researches and the closing session (to be followed by a reception at the Hôtel de Ville and a banquet) by the Minister for the Colonies. Admission to membership of the Conference involves payment of a fee of 100 francs, exclusive of the charge of 40 franes for participation in the banquet. Membership will carry the right of free entry to the Exhibition during the Conference. The address of the secretariat is : Laboratory of Applied Entomology, 45 bis, rue de Buffon, Paris, $5^{\mathrm{e}}$. The secretariat will, if desired, reserve bedrooms for members.

\section{Comet Finsler}

Predrction for the place of Finsler's Comet for the next three weeks is given in Announcement Card No. 421 issued by Harvard College Observatory. The ephemeris is based on a parabolic orbit computed by Dr. A. D. Maxwell of the University of Michigan. The time of deduced perihelion passage is August 15.76946 U.T. This comet was discovered on July 4 last by Finsler at Zurich; it was then of the 7 th magnitude. It is now possible to locate the comet with the naked eye. The following predicted positions at $0^{\text {h }}$ U.T. show that the comet will pass $3^{\circ}$ or $4^{\circ}$ 
west of the bright star, Arcturus, between August 22 and 23. In the latitude of London, Arcturus sets in the north-west about an hour after midnight (Summer Time) in the middle of the month.

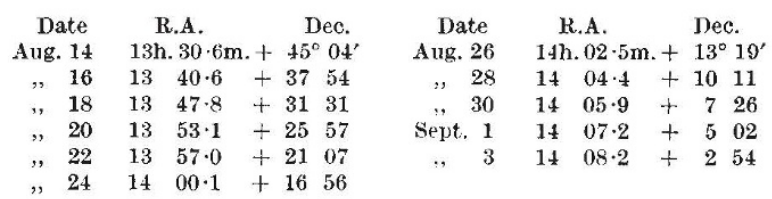

\section{Announcements}

THE following research fellowships in tropical medicine have recently been awarded by the Medical Research Council : Senior fellowship to Dr. Frank Hawking, assistant lecturer in pharmacology, Welsh National School of Medicine, Cardiff; this is tenable for three years, for investigations to be made mainly in the tropics. Dr. Hawking will work in Africa on the chemotherapeutic treatment of sleeping sickness. Junior fellowships: D. A. Cannon; J. L. Dales, assistant pathologist, Royal Hospital, Sheffield; I. W. MacKichan, house surgeon, London Hospital.

ON the recommendation of the Agricultural Research Council the following awards of agricultural research scholarships, studentships for research in animal health and veterinary scholarships have been made by the Ministry of Agriculture and Fisheries and the Department of Agriculture for Scotland: P. J. Faulks (plant physiology), R. S. Russell (plant physiology), F. H. Malpress (nutritional chemistry), J. Wilson (plant genetics), G. H. L. Dicker (entomology), J. W. Whittick (animal pathology), F. D. Asplin (poultry diseases), Miss K. M. Massey (poultry diseases).

THE following awards for 1937-38 have recently been made by the Salters' Institute for Industrial Chemistry and approved by the Court of the Salters' Company : a fellowship has been renewed to L. M. Baxt, Imperial College; fellowships have been awarded to R. H. Freak, University of Oxford, A. J. Shorter, University of Birmingham, J. L. Tuck, University of Manchester, and S. H. Wade, Imperial College of Science and Technology; the Salters' Institute has also awarded forty grants-in-aid to young men employed in chemical works in or near London to assist them in their studies.

Dr. J. Anderson has been appointed representative of the Scottish Beekeepers' Association on the Bee Research Committee that advises it in regard to investigations on bees carried out at Rothamsted. Dr. Anderson is well known for his special knowledge of bee problems and for his admirable work in Scotland in applying science to the solution of the beekeepers' difficulties.

Eight honorary memberships of the Engineering Institute of Canada were conferred at the semicentennial meeting of the Society held in Montreal recently. The engineers honoured include Sir Alex- ander Gibb, president of the Institution of Civil Engineers; the Hon. C. D. Howe, Minister of Transport, Ottawa ; the Hon. Grote Stirling, former Minister of National Defence, Kelowna ; Prof. R. W. Angus, professor of mechanical engineering at the University of Toronto ; Dr. George Herrick Duggan, a past-president of the Engineering Institute of Canada and chairman of the Dominion Bridge Company, Montreal; and Mr. S. J. Hungerford, chairman and president of the Canadian National Railways, Montreal.

DR. JohN K. SmaLL, chief research curator of the New York Botanical Garden, who has described the proposed Everglades National Park on p. 263 of this issue, has sent us sixty papers, of diverse botanical interest, published in the Journal of the New York Botanical Garden, and extending over a period of twenty years. The papers demonstrate great field activity on the part of the author, especially in plant morphology and ecology. It is interesting to note that Dr. Small has published about a hundred reports on explorations and fourteen descriptive floras concerned chiefly with the south-eastern United States. Copies of these publications can be obtained from the Science Press Printing Co., Lime and Green Streets, Lancaster, Pasadena.

Dr. Adolf Butenandt, director of the Kaiser Wilhelm Institute for Biochemistry, has been awarded the Scheele Medal of the Chemical Society of Stockholm.

Geheimrat Prof. Carl Bosch has been elected president of the Kaiser Wilhelm Society for the Advancement of Science in succession to Prof. Max Planck.

THE Gluge Prize of physiology of the Belgian Royal Academy of Sciences has been awarded to Prof. J. J. Bouckaert of the University of Ghent.

Dr. Victor G. Heiser has been awarded the Medal for Distinguished Service of the Pennsylvanian Society of New York in recognition of his medical research work under the auspices of the Rockefeller Foundation.

THE sixteenth American Congress of Physical Therapy will be held in Cincinnati, Ohio, on September 20-24 at the Netherlands Plaza Hotel, under the presidency of Dr. William Bierman of New York. Further information can be obtained from the editorial and executive offices of the Congress, 30 North Michigan Avenue, Chicago.

AN International Congress of the Scientific Press organized by the Professional Syndicate of the Scientific Press will be held in Paris on October 7-9. Further information can be obtained from M. Toutain, 25 rue du Four, Paris.

Erratum. In Nature of August 7, p. 229, the date of the erection of the Roman bath at Leicester should be, obviously, A.D. and not B.C. as stated. 